\title{
Resilient Built Environment: Critical Review of the Strategies Released by the Sustainability Rating Systems in Response to the COVID-19 Pandemic
}

\author{
Antonio Marotta *(D), César Porras-Amores (D) and Antonio Rodríguez Sánchez
}

check for updates

Citation: Marotta, A.; Porras-Amores, C.; Rodríguez Sánchez, A. Resilient Built Environment: Critical Review of the Strategies Released by the Sustainability Rating Systems in Response to the COVID-19 Pandemic. Sustainability 2021, 13, 11164. https:// doi.org/10.3390/su132011164

Academic Editor: Abdollah

Shafieezadeh

Received: 31 August 2021

Accepted: 5 October 2021

Published: 10 October 2021

Publisher's Note: MDPI stays neutral with regard to jurisdictional claims in published maps and institutional affiliations.

Copyright: (c) 2021 by the authors. Licensee MDPI, Basel, Switzerland. This article is an open access article distributed under the terms and conditions of the Creative Commons Attribution (CC BY) license (https:// creativecommons.org/licenses/by/ $4.0 /)$.
Departamento de Construcciones Arquitectónicas y su Control, Escuela Técnica Superior de Edificación (UPM), Universidad Politécnica de Madrid, Avenida Juan de Herrera, 6, 28040 Madrid, Spain; c.porras@upm.es (C.P.-A.); antonio.rodriguezs@upm.es (A.R.S.)

* Correspondence: antonio.marotta@alumnos.upm.es

Abstract: Since the COVID-19 outbreak, buildings have been viewed as a facilitator of disease spread, where the three main transmission routes (contact, droplets, aerosols) are more likely to happen. However, with proper policies and measures, buildings can be better prepared for re-occupancy and beyond. This study reviews the strategies developed by several Sustainability Rating Systems (SRS, namely WELL, Fitwel and LEED) to respond to any infectious disease and ensure that building occupants protect and maintain their health. The best practices, that are similar between each SRS, highlight that the overall sustainability of the spaces increases if they are resilient. Results indicate that SRS promote a weak sustainability approach since they accept that economic development can reduce natural capitals. SRS are also characterized by an aggregated level of assessment of different criteria that does not allow to map different choices. However, the decomposition of the concept of sustainability in its three bottom lines (i.e., environmental, social and economic) shows that preventive strategies are likely to be systematically adopted as the state-of-the-art. Finally, even if the latest research points out the airborne transmission as the major infection route, the SRS lack analytical measures to address issues such as social distancing.

Keywords: SARS-CoV-2; COVID-19; respiratory disease transmission; indoor environmental quality; sustainability rating systems; green buildings; healthy buildings; LEED; WELL; Fitwel

\section{Introduction}

Coronaviruses $(\mathrm{CoV})$ are a family of positive-sense single-stranded RNA respiratory viruses, meaning that they have ribonucleic acid as genetic material [1]. Their name comes from the crown-shaped tips present on their surface, and they cause several human diseases, from influenza to Ebola [2].

At the end of 2019, a new type of disease (later named as coronavirus disease 2019, or COVID-19) broke out in Wuhan, the capital of Hubei Province in China [3-5]. Doctors discovered that it was caused by a new strain of the coronavirus family, SARS-CoV-2 [6,7]. It belongs to the same family as SARS-CoV-1, responsible for the severe acute respiratory syndrome (SARS) epidemic in June 2003 [8], and MERS-CoV, the Middle East respiratory syndrome of June 2012 [9].

The World Health Organization (WHO, Geneva, Switzerland) declared the infectious disease an epidemic during its initial outbreak in Wuhan, a pandemic on 11 March 2020 once COVID-19 had spread all over the world without control and, finally, an endemic infection that may remain in our communities [10].

When it comes to epidemiology, the parameter $R$ is used to measure the spread of infective diseases between the population. If $R$ is two, two infected people will, on average, infect four others, who will infect eight others, and so on [11]. The spread of an infection is typically considered under control when $R$ is lower than 1 [10]. SARS-CoV-2 has a basic 
reproductive rate $\left(\mathrm{R}_{0}\right)$ of 2.5 (range 1.8-3.6), compared to 2.0-3.0 estimated for SARS-CoV-1 and 0.9 estimated for MERS-CoV [12].

MERS-CoV is the most lethal coronavirus, since it often progresses to severe pneumonia with a mortality rate higher than 30\%. Similarly, SARS-CoV-1 causes fever, chills and body aches, and often progresses to pneumonia, with a mortality rate of about $10 \%$. SARS-CoV-2, which shows the lower mortality rate (about 2.3\%) [13], produces infections in people that can be totally asymptomatic or that can present flu-like symptoms such as fever, cough and breathing difficulties [14]. The most severe symptomatology is more frequent in elderly subjects, in people with concomitant pathologies [15], or in young subjects with a weak immune system (i.e., undergoing acute or chronic immunosuppressive therapy) [16]. Symptomatology is also shown in subjects with a decreased immune defense due to an excessive workload [17], or those who work night shifts with irregularities of the normal circadian sleep-wake rhythm [18]. Patients that develop pneumonia, a severe condition in which the lungs become inflamed and fill with pus [13], can ultimately die due to multiple organ failure [7].

Even if the reproductive rate and the fatality rate of SARS-CoV-2 are different from its predecessors, the modality of transmission is comparable to the epidemics caused by other coronaviruses. The virus enters the body through access routes such as the oral cavity, the nasal cavity, the eyes and other mucous membranes [19], and as shown in Figure 1, three main transmission routes have been identified [20]:
1. Contact.
2. Droplets.
3. Aerosols.

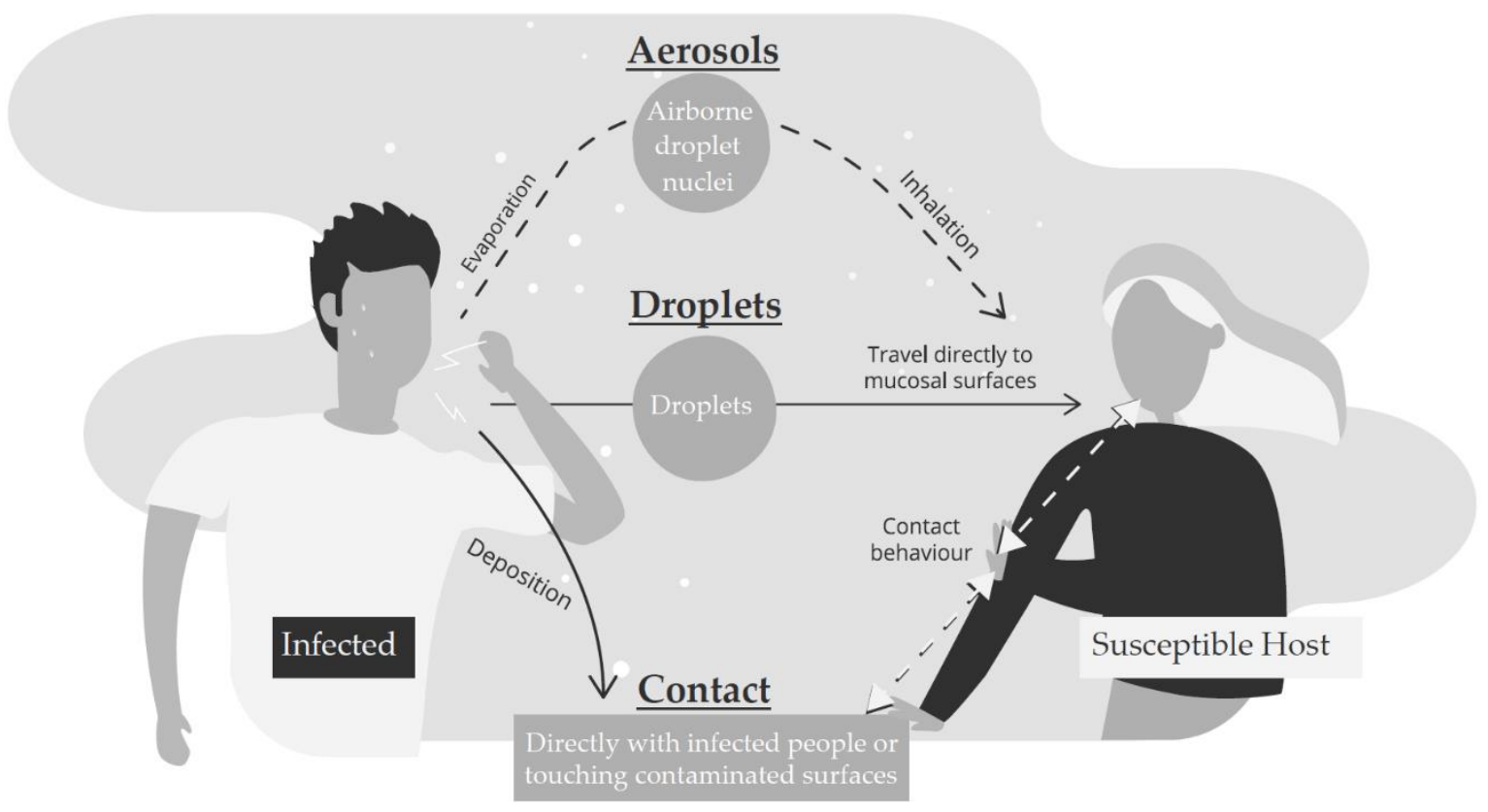

Figure 1. The three primary routes for infectious transmission during social interaction [21,22].

Contact can take place directly with infected people or indirectly by depositing droplets containing the virus on any person (handshake, greeting, hug) or surface (fomite) [23]. Droplets are generated during speaking, coughing and sneezing both by symptomatic patients and asymptomatic people [20]. The risk of airborne cross-infection is defined as the proportion of air mass exhaled by the infected person that is then inhaled by the exposed person [24]. Face-to-face and conversational exposure transmission are the most typical short-range airborne routes [25].

Aerosols are airborne microparticles with a diameter smaller than $5 \mu \mathrm{m}$, which are transported by the flow of the air current, even at a considerable distance (long-range) [19]. 
The inhalation of aerosols containing pathogens is also possible because SARS-CoV-2 remains practicable in aerosols for hours [26].

It is difficult to quantitatively compare the relative contribution of airborne transmission with other transmission modes (i.e., contact and droplets). In fact, infection may occur via all routes to different degrees depending on the specific exposure circumstances. Therefore, effective infection control necessitates protection against all exposure pathways. If medical and biological factors are considered (e.g., infectious dose) along with the engineering factors, the comparison becomes even more sophisticated [27]. However, several studies provide strong evidence for indoor airborne transmission of viruses, particularly in crowded and poorly ventilated environments [28,29]. Infectious pandemics that happened in the past forced the development of new strategies in the built environment as a contribution towards preventing the spread of infections. These measures helped not only to reduce the risk of disease transmission (or even prevent it), but also to increase the resilience of the built environment [30].

BREEAM defines resilience as "the capacity of built assets to endure acute shocks and chronic stresses while successfully adapting to long-term changes". Resilience is seen as "an integral part of sustainability that creates a better future for the environment and society" [31].

Some authors agree with the fact that pandemics and extreme events resulting from climate change are warnings from the planet that the limits may have been reached and that a more structural approach should be adopted, combining environmental concerns with the focus on sustainability [30,32].

The greatest historical pandemics have leveraged changes designed to introduce protective measures into buildings that are summarized in Table 1. In fact, the built environment not only increases or decreases exposure conditions (i.e., lack of water or poor air ventilation), but it can also create diseases (i.e., HVAC, indoor plumbing and hot water systems can create new conditions for the spread of Legionnaire's disease) $[30,33]$.

Table 1. Historical infectious diseases and their implications for the built environment [30].

\begin{tabular}{|c|c|c|}
\hline $\begin{array}{c}\text { Epidemiological } \\
\text { Disease }\end{array}$ & Period & Measures on the Built Environment \\
\hline Infectious diseases & 2nd century & $\begin{array}{l}\text { Aqueducts, water and } \\
\text { sanitation systems [34]. }\end{array}$ \\
\hline $\begin{array}{l}\text { Black Death/ } \\
\text { Bubonic Plague }\end{array}$ & 14th century & $\begin{array}{l}\text { Larger public spaces with } \\
\text { more organized layouts [35]. }\end{array}$ \\
\hline Cholera & 19th century & $\begin{array}{l}\text { Sanitation of sewage systems to stop } \\
\text { fecal-oral transmission route }[36,37] \text {. }\end{array}$ \\
\hline $\begin{array}{l}\text { Tuberculosis/ } \\
\text { White Plague }\end{array}$ & 19th century & $\begin{array}{l}\text { Modern minimal design with terraces, balconies } \\
\text { and flat roofs to capture sunlight and air }[38,39] \text { and reject } \\
\text { dust, pollution and diseases }[40] \text {. }\end{array}$ \\
\hline Spanish Flu & 20th century & Social distancing and gauze masks [41,42]. \\
\hline SARS-CoV-1 & 21st century & $\begin{array}{l}\text { Taking people's temperatures [8] and } \\
\text { improved ventilation and drainage systems [43]. }\end{array}$ \\
\hline
\end{tabular}

\section{Aim and Purpose}

The introduction highlights the epidemiology and symptomatology of SARS-CoV-2, whose foundations come from sources collected between 2020 and early 2021, as shown in the Reference Section. Due to the hot topic, some values and parameters may vary in the future, but the general concepts are consolidated, given the experience with previous infectious diseases. The introduction also focuses on the transmission routes of the virus and the behavior of droplets and aerosols in indoor spaces.

The U.S. Centers for Disease Control (CDC) represents a hierarchy of infection control from the most to the least effective [44]:

- Elimination: physical removal of the hazard. 
- Substitution: replace the hazard.

- Engineering controls: isolate people from the hazard.

- Administrative controls: change the way people work.

- PPE: protect the workers with personal protective equipment [44].

With such a background, the aim of this study is to review the strategies specifically developed in response to the COVD-19 pandemic and valid in case of any infectious disease. They are meant to reduce exposures to occupational hazards inside the regularly occupied indoor environment, where cross-infection is more likely to happen. If spaces are resilient, their overall sustainability increases. For this reason, this study aims to critically review the strategies developed within the most recognized Sustainability Rating Systems (SRS), which can be defined as the process of identifying, measuring and evaluating the potential impacts of alternatives for sustainability. Even though they are characterized by some limitations, SRS are globally recognized tools to assess building sustainability due to their solidity and applicability [45].

The manuscript aims to clarify two aspects that are not critically reviewed in the state-of-the-art:

1. Any lack within the strategies developed by the Sustainability Rating Systems specifically to minimize the transmission of infectious diseases.

2. The level of sustainability of the above-mentioned strategies addressed in response to the COVID-19 pandemic.

Sustainability Rating Systems are constantly updated in order to meet the industry development and achieve a reasonable balance among the three pillars or triple bottom line of sustainability, namely, environmental, social and economic sustainability [46], as shown in Figure 2.

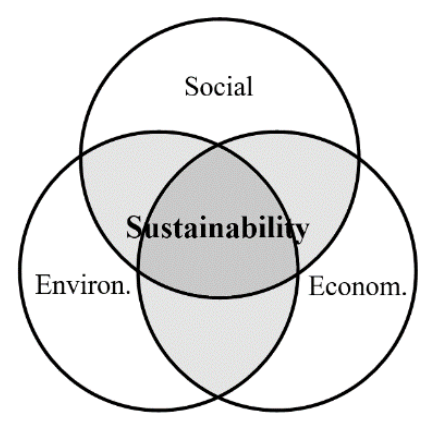

Figure 2. The three pillars of sustainability.

Even though this represents a simplification of a complex concept such as sustainability, the decomposition allows to measure the level of sustainability of each strategy in a more methodic and accurate way. In particular, this study analyzes the degree of sustainability of the measures addressed by the SRS in response to the COVD-19 pandemic.

The last decades of the SRS have been characterized by a slight decrease in the weight of the environmental category, an increase in the weight of the social category and a minor rise in the weight of the economic category. In particular, within the social category, wellbeing has the highest proportion, with physical comfort showing the fastest growth [46].

Among the SRS, "Green Building Rating Systems" (GBRS) have the environmental sustainability as their primary motivator, while "Healthy Building Rating Systems" (HBRS) are mainly focused on occupant health and wellness. While the first ones have been established for almost 30 years, the latter are more recent. Developed upon the health-related credits of GBRS, HBRS leverage academic research to prescribe measures to create workspaces that reduce absenteeism and enable wellness and productivity of their occupants through prescriptive limitations as well as performance-based credits [47]. 
Lately, GBRS have been incorporating more and more requirements for occupant health and wellness, showing the increasing interest in this area by both building designers and end-users. Besides, the Real Estate sector has also demonstrated an increased interest in this area, as evidenced by the amount of assets registered under the HBRS [47].

The consistent spread of SRS across different regions and asset classes can be found in their nature: they are intuitive and practical tools useful to design a built environment resilient to infectious diseases. Most of the evidence-based measures within them, spanning building design and operations, as well as company policies and behavioral changes, provide a practical framework for buildings and occupants responding to the pandemic and preparing for a safer and healthier future. For this reason, the aim of this work is to review applicable strategies that reflect how stakeholders can approach prevention and preparedness, resilience and recovery in response to COVID-19 or any other respiratory diseases [48].

In the literature, there are several studies that explore the evolution of Sustainability Rating Systems and their multi-criterion nature based on indicators and benchmarks [49]. However, no papers in scientific journals investigate the evidence-based best practices developed to mitigate the spread of infectious diseases and their level of sustainability.

\section{Methodology}

Among the dozens of Sustainability Rating Systems available all across the globe, this study assesses in detail WELL, Fitwel and LEED. In fact, they have been the only ones to officially publish ad-hoc strategies in response to the COVID-19 pandemic, even though other Ratings have also highlighted the importance of transmission control inside the built environment [50,51].

\subsection{Publications}

The first was the WELL Building Standard, managed and administered by the International WELL Building Institute (IWBI), whose Task Force released the WELL Health-Safety Rating for Facility Operations and Management in June 2020 to help guide stakeholders to evidence-based best practices for navigating through the crisis, as well as for long-term preparedness on any other critical health and safety issues [52].

WELL was immediately followed by LEED, managed and administered by the U.S. Green Building Council (USGBC), that released six LEED pilot credits in June 2020 to help building teams provide healthy spaces, and to assist with re-entry [53].

Finally, Fitwel, originally created by the U.S. Centers for Disease Control (CDC) and Prevention and U.S. General Services Administration, in September 2020 released the Fitwel Viral Response module in direct response to industry demand surrounding the COVID-19 pandemic [54].

\subsection{Scope of Application}

The SRS considered in the review share the following nature:

- Internationally applicable (not country-specific).

- Voluntary (standards and codes are excluded).

- Focused on buildings in operation with a defined fit-out.

- $\quad$ Referred to mechanical ventilated workspaces.

They are all internationally applicable because they are based on the belief that the occupants of buildings based, for instance, in America, Asia or Europe, have similar needs, even if the assets have different boundary conditions.

They are voluntary; therefore, the strategies are more demanding than the minimum requirements included in a typical local standard or code.

They refer to buildings in use because most of the strategies are operations policies and maintenance procedures of already occupied spaces.

They consider office spaces because they are commonly recognized as the main vectors for the transmission of infectious diseases [30,55]. 
This is particularly important considering that workplaces must face a post-pandemic future, with a hybrid virtual model that combines remote work with time in the office, according to a survey from McKynsey \& Company [56]. In fact, while productivity increased during the pandemic, many employees reported feeling anxious and burned out and a provision of a safe workplace seems essential.

Assets that do not reflect the four characteristics (i.e., buildings under construction or in a core and shell state, residential buildings, etc.) should also follow the recommended strategies from an early stage to enhance an integrated design process [57-60].

\subsection{Degree of Sustainability}

This study aims to measure the degree of sustainability of the strategies addressed by the Sustainability Rating Systems to minimize the transmission of infectious diseases. To do so, the concept of sustainability is decomposed in its three bottom lines, namely, environmental, social and economic. Even though this represents a simplification, the process allows to determine the level of sustainability of each strategy in the most accurate way.

Since the measures are intended to enhance the human health and safety, the social component is the main target of every strategy. However, the environmental and economic components vary consistently. For instance, if a strategy has high levels of environmental and economic sustainability, it can be defined as sustainable itself. On the contrary, if a strategy is neither environmentally friendly nor economically feasible, its overall degree of sustainability decreases.

Therefore, in the Results Section, each strategy is scored according to its level of environmental and economic sustainability, as shown in Table 2.

Table 2. Degree of sustainability scores' equivalences.

\begin{tabular}{ccc}
\hline Degree of Sustainability & Environmental Sustainability & Economic Sustainability \\
Low & $\begin{array}{c}\text { The impact on the environment is consistent } \\
\text { as regards the use of natural resources } \\
\text { (materials, water, energy, etc.) } \\
\text { The impact on the environment is } \\
\text { comparable to similar buildings } \\
\text { Thedium }\end{array}$ & $\begin{array}{c}\text { The capex needed to implement the strategy is } \\
\text { consistent and characterized by a payback longer } \\
\text { than the lifecycle of the building } \\
\text { environment is negligible }\end{array}$ \\
High & $\begin{array}{c}\text { The return on investment (ROI) of the strategy } \\
\text { implemented is typically less than a decade } \\
\text { The cost needed to implement the strategy can be } \\
\text { easily put in the operating budget of the building in } \\
\text { use (opex) }\end{array}$ \\
\hline
\end{tabular}

\subsection{Extents and Limitations}

The strategies released by the SRS are also assessed in order to highlight any lack present among them with respect to the behavior of infectious diseases presented in the introduction.

Finally, this study is intended to critically review the approach of the SRS with regards to the concept of sustainability itself. Sustainable development was initially defined as a development that meets the needs of the present without compromising the ability of future generations to meet their own needs [61]. This simplification describes a weak sustainability approach, characterized by the possibility to substitute economy and nature to achieve the goal of the highest possible utility for humans [62]. The weak sustainability approach assumes that natural capital and manufactured capital are essentially substitutable and that there are no essential differences between the kinds of well-being they produce. The only thing that matters is the total value of the aggregate stock of capital [63]. This is also reflected in the three pillars of sustainability whose aggregate defines the sustainable development. No restriction on the degree of substitutability between natural and manufactured capital is introduced, thus an economy is considered sustainable if its savings rate is greater than the combined depreciation rate on human-made and natural capital [64]. On the other hand, strong sustainability requires non-decreasing natural capital due to the existence of critical thresholds, beyond which any decrease in a physical unit of natural capital cannot 
be replaced by an increase in the quantity of other forms of capital [64]. This approach assumes that the substitutability between natural capital and other forms of capital should be strictly limited to the circumstances where the use of the services provided by natural capital does not lead to the irreversible destruction of this capital because its depletion cannot be compensated by investing in other forms of capital [63].

SRS generally promote a weak sustainability approach and accept that economic development can reduce natural capitals. Its implications are discussed in the Discussion Section.

\section{Results}

This section is intended to show the measures released by the Sustainability Rating Systems to prevent the spread of infectious diseases in indoor spaces. The focus is on WELL, Fitwel and LEED, that have been the only ones to officially publish ad-hoc strategies in response to the COVID-19 pandemic, and that are critically compared at the end.

\subsection{WELL Health-Safety Rating}

The WELL Building Standard, managed and administered by the International WELL Building Institute (IWBI), is the most common HBRS to implement, validate and measure features that support and advance human health and wellness. WELL was developed by integrating scientific and medical research and literature on environmental health, behavioral factors, health outcomes and demographic risk factors that affect health with leading practices in building design, construction and management [52].

In late March 2020, IWBI's Task Force on COVID-19 and Other Respiratory Infections, a group of nearly 600 public health experts, virologists, government officials, academics, business leaders, architects, designers, building scientists and real estate professionals, was established to support the response to the pandemic. This group identified an important need for a third-party designation that would guide stakeholders towards evidence-based best practices for mitigating the effects of the pandemic and for overcoming this crisis and beyond [65].

As a result, the WELL Health-Safety Rating for Facility Operations and Management was released to help guide organizations to evidence-based best practices for operating through the crisis (immediate strategies), as well as for long-term preparedness on other critical health and safety issues (long-term strategies) [65].

The WELL Health-Safety Rating includes 21 features across the following core areas:

- $\quad$ Cleaning and Sanitization Procedures.

- $\quad$ Emergency Preparedness Programs.

- Health Service Resources.

- $\quad$ Air and Water Quality Management.

- Stakeholder Engagement and Communication.

- Innovation [65].

The detail of each strategy addressed by the WELL Health-Safety Rating is available in the Supplementary Material of the manuscript.

\subsection{Fitwel Viral Response Module}

Fitwel is another internationally recognized HBRS. Originally created by the U.S. Centers for Disease Control (CDC) and Prevention and U.S. General Services Administration, Fitwel is implementing a vision for a healthier future where all buildings and communities are enhanced to strengthen health and well-being. Currently, the Center for Active Design is the licensed operator of Fitwel, charged with expanding Fitwel to the global market [54].

The Fitwel Viral Response module was developed in direct response to industry demand surrounding the COVID-19 pandemic. It establishes data-driven strategies that mitigate viral transmission, build trust and create healthy environments for all occupants. Those strategies can minimize the spread of any infectious respiratory diseases, including influenza and legionnaires' disease [54]. 
The Fitwel Viral Response module covers three key topic areas for mitigating infectious disease transmission:

- $\quad$ Enhance Indoor Environments.

- Encourage Behavioral Change.

- $\quad$ Build Occupant Trust [66].

The detail of each strategy addressed by the Fitwel Viral Response module is available in the Supplementary Material of the manuscript.

\subsection{LEED Safety First Pilot Credits}

Developed by the U.S. Green Building Council (USGBC), Leadership in Energy and Environmental Design (LEED) is the most recognized GBRS. Its first version, LEED for New Construction and Major Renovations, was developed in 1998 and was updated multiple times over the years with a variety of other rating systems. LEED seeks to optimize the use of natural resources, promote regenerative and restorative strategies and maximize the positive and minimize the negative environmental and human health consequences of the building industry. The ongoing improvements also aim toward high-quality indoor environments for building occupants [67].

In summer 2020, USGBC released six LEED pilot credits to help building teams provide healthy spaces, and to assist with re-entry. The pilot credits outline sustainable best practices that align with public health and industry guidelines related to cleaning and disinfecting, workplace re-occupancy, HVAC and plumbing operations and pandemic preparedness and response [68].

The first four credits are specifically developed for certified LEED projects or undergoing certification, while the last two are available for LEED for Cities and Communities [68].

The detail of each strategy addressed by the LEED Safety First Pilot Credits is available in the Supplementary Material of the manuscript.

\subsection{Other Sustainability Rating Systems}

WELL, Fitwel and LEED developed specific ratings, modules and credits as best practices for mitigating the spread of COVID-19 and to prevent, prepare and recover from any respiratory disease.

Other globally recognized Sustainability Rating Systems have underlined the most effective measures to respond to the pandemic among the strategies already implemented in the Ratings.

The Building Research Establishment (BRE), responsible for the first ever GBRS Building Research Establishment Environmental Assessment Method (BREEAM), recently published the paper "Building back better with BREEAM" to support the green recovery. BREEAM enhances public health and wellbeing, an equitable built environment and resilience to support a better future and a preparedness for any pandemic scenario [50].

The Regenerative Ecological, Social and Economic Targets (RESET) is an international performance standard and certification program for healthy buildings based on data that are collected and analyzed on a daily basis [69]. Although it is currently impossible to measure airborne viruses in real-time, it is possible to measure a building's ability to minimize the potential of infection from airborne (in particular aerosol) transmission in realtime across a range of parameters. After months of research, RESET released two Indexes focused on optimizing indoor environments against airborne viral infections. The RESET Index for Building Optimization calculates the optimal Indoor Air Quality environment, while the RESET Index for Airborne Infection Potential calculates the potential for infection based on the Indoor Air Quality metrics that can be controlled by a building's or indoor space's air system. The results enable users to gain insight into an indoor space's level of optimization based on a few Indoor Air Quality metrics (temperature, humidity, carbon dioxide and airborne particles) [51]. 


\subsection{Comparison of the Strategies}

As shown in the previous chapters, the SRS that released ad-hoc strategies in response to COVID-19 are WELL, Fitwel and LEED. They are available in detail in the Supplementary Material of the manuscript. For each measure analyzed, Table 3 summarizes its scope and category, that are helpful to identify similar strategies between the different SRS (i.e., Support Handwashing in WELL and Hand Hygiene in Fitwel).

Table 3. Sustainability Rating Systems' strategies in response to the COVID-19 pandemic.

\begin{tabular}{|c|c|c|c|c|c|}
\hline \multirow{2}{*}{ Rating System } & \multirow{2}{*}{ Strategy } & \multirow{2}{*}{ Scope } & \multirow{2}{*}{ Category } & \multicolumn{2}{|c|}{ Sustainability } \\
\hline & & & & Environment & Economic \\
\hline WELL & Support Handwashing & Cleaning and sanitization & Built Environment & High & High \\
\hline WELL & Reduce Surface Contact & Cleaning and sanitization & Built Environment & High & Medium \\
\hline WELL & Improve Cleaning Practices & Cleaning and sanitization & Built Environment & High & High \\
\hline WELL & $\begin{array}{l}\text { Select Preferred Cleaning } \\
\text { Products }\end{array}$ & Cleaning and sanitization & Built Environment & High & Medium \\
\hline WELL & $\begin{array}{l}\text { Reduce Respiratory Particle } \\
\text { Exposure }\end{array}$ & Cleaning and sanitization & Built Environment & High & Medium \\
\hline WELL & $\begin{array}{c}\text { Develop Emergency Preparedness } \\
\text { Plan }\end{array}$ & $\begin{array}{l}\text { Emergency Preparedness } \\
\text { Programs }\end{array}$ & Built Environment & High & High \\
\hline WELL & $\begin{array}{l}\text { Create Business } \\
\text { Continuity Plan }\end{array}$ & $\begin{array}{c}\text { Emergency Preparedness } \\
\text { Programs }\end{array}$ & Company Policy & High & High \\
\hline WELL & Plan for Healthy Re-Entry & $\begin{array}{c}\text { Emergency Preparedness } \\
\text { Programs }\end{array}$ & Company Policy & High & High \\
\hline WELL & Provide Emergency Resources & $\begin{array}{c}\text { Emergency Preparedness } \\
\text { Programs }\end{array}$ & Company Policy & High & High \\
\hline WELL & Bolster Emergency Resilience & $\begin{array}{c}\text { Emergency Preparedness } \\
\text { Programs }\end{array}$ & Company Policy & High & High \\
\hline WELL & Provide Sick Leave & Health Service Resources & Company Policy & High & Medium \\
\hline WELL & Provide Health Benefits & Health Service Resources & Company Policy & High & Medium \\
\hline WELL & Support Mental Health Recovery & Health Service Resources & Company Policy & High & Medium \\
\hline WELL & Promote Flu Vaccines & Health Service Resources & Company Policy & High & Medium \\
\hline WELL & $\begin{array}{c}\text { Promote a Smoke-Free } \\
\text { Environment }\end{array}$ & Health Service Resources & Company Policy & High & High \\
\hline WELL & Assess Ventilation & $\begin{array}{l}\text { Air and Water Quality } \\
\text { Management }\end{array}$ & Built Environment & Medium & Low \\
\hline WELL & $\begin{array}{l}\text { Assess and Maintain Air } \\
\text { Treatment Systems }\end{array}$ & $\begin{array}{l}\text { Air and Water Quality } \\
\text { Management }\end{array}$ & Built Environment & High & Low \\
\hline WELL & $\begin{array}{c}\text { Develop Legionella Management } \\
\text { Plan }\end{array}$ & $\begin{array}{c}\text { Air and Water Quality } \\
\text { Management }\end{array}$ & Built Environment & High & Medium \\
\hline WELL & Monitor Air and Water Quality & $\begin{array}{l}\text { Air and Water Quality } \\
\text { Management }\end{array}$ & Built Environment & High & High \\
\hline WELL & Manage Mold and Moisture & $\begin{array}{c}\text { Air and Water Quality } \\
\text { Management }\end{array}$ & Built Environment & High & High \\
\hline WELL & Promote Health and Wellness & $\begin{array}{l}\text { Stakeholder Engagement and } \\
\text { Communication }\end{array}$ & Company Policy & High & High \\
\hline WELL & $\begin{array}{l}\text { Share Food Inspection } \\
\text { Information }\end{array}$ & $\begin{array}{l}\text { Stakeholder Engagement and } \\
\text { Communication }\end{array}$ & Company Policy & High & High \\
\hline Fitwel & $\begin{array}{c}\text { Enhanced Indoor Air Quality } \\
\text { Policy }\end{array}$ & Enhance Indoor Environment & Built Environment & Medium & Low \\
\hline Fitwel & Humidity Control Policy & Enhance Indoor Environment & Built Environment & Medium & Medium \\
\hline Fitwel & $\begin{array}{l}\text { Enhanced Indoor Air Quality } \\
\text { Testing and Monitoring Protocol }\end{array}$ & Enhance Indoor Environment & Built Environment & High & Low \\
\hline Fitwel & $\begin{array}{c}\text { Legionella Water Management } \\
\text { Plan }\end{array}$ & Enhance Indoor Environment & Built Environment & High & Medium \\
\hline Fitwel & $\begin{array}{l}\text { Enhanced Cleaning, Disinfecting, } \\
\text { and Maintenance Protocol }\end{array}$ & Enhance Indoor Environment & Built Environment & High & High \\
\hline Fitwel & $\begin{array}{c}\text { Enhanced Green Purchasing } \\
\text { Policy }\end{array}$ & Enhance Indoor Environment & Built Environment & High & Medium \\
\hline Fitwel & Surface Hygiene Stations & Encourage Behavioral Change & Built Environment & High & Medium \\
\hline Fitwel & $\begin{array}{l}\text { Personal Protective Equipment } \\
\text { (PPE) } \\
\text { Guidelines }\end{array}$ & Encourage Behavioral Change & Company Policy & High & High \\
\hline Fitwel & $\begin{array}{l}\text { Personal Protective Equipment } \\
\text { (PPE) Provision Plan }\end{array}$ & Encourage Behavioral Change & Company Policy & High & Medium \\
\hline Fitwel & Hand Hygiene & Encourage Behavioral Change & Company Policy & High & Medium \\
\hline Fitwel & Health Promotion Signage & Encourage Behavioral Change & Company Policy & High & High \\
\hline Fitwel & $\begin{array}{c}\text { Specialized Health Programming } \\
\text { and Services Plan }\end{array}$ & Encourage Behavioral Change & Company Policy & High & Medium \\
\hline
\end{tabular}


Table 3. Cont.

\begin{tabular}{|c|c|c|c|c|c|}
\hline \multirow{2}{*}{ Rating System } & \multirow{2}{*}{ Strategy } & \multirow{2}{*}{ Scope } & \multirow{2}{*}{ Category } & \multicolumn{2}{|c|}{ Sustainability } \\
\hline & & & & Environment & Economic \\
\hline Fitwel & Social Support Groups & Encourage Behavioral Change & Company Policy & High & High \\
\hline Fitwel & $\begin{array}{c}\text { Contagious Disease Outbreak } \\
\text { Preparedness Plan }\end{array}$ & Build Occupant Trust & Company Policy & High & High \\
\hline Fitwel & Business Continuity & Build Occupant Trust & Company Policy & High & High \\
\hline Fitwel & Mental Health First Aid & Build Occupant Trust & Company Policy & High & High \\
\hline Fitwel & Viral Response Design Guidelines & Build Occupant Trust & Company Policy & High & High \\
\hline Fitwel & $\begin{array}{c}\text { Enhanced Stakeholder } \\
\text { Collaboration Plan }\end{array}$ & Build Occupant Trust & Company Policy & High & High \\
\hline Fitwel & Communication Plan & Build Occupant Trust & Company Policy & High & High \\
\hline Fitwel & Paid Sick Leave Policy & Build Occupant Trust & Company Policy & High & High \\
\hline Fitwel & Family Support Policy & Build Occupant Trust & Company Policy & High & High \\
\hline LEED & Re-Enter Your Workspace & Building Operation & Built Environment & High & Medium \\
\hline LEED & $\begin{array}{c}\text { Cleaning and Disinfecting Your } \\
\text { Space }\end{array}$ & Building Operation & Built Environment & High & Medium \\
\hline LEED & $\begin{array}{l}\text { Managing Indoor Air Quality } \\
\text { during COVID-19 }\end{array}$ & Building Operation & Built Environment & Medium & Low \\
\hline LEED & $\begin{array}{l}\text { Building Water System } \\
\text { Recommissioning }\end{array}$ & Building Operation & Built Environment & High & Medium \\
\hline LEED & Pandemic Planning & Cities and Communities & Company Policy & High & High \\
\hline LEED & $\begin{array}{c}\text { Social Equity in Pandemic } \\
\text { Planning }\end{array}$ & Cities and Communities & Company Policy & High & High \\
\hline
\end{tabular}

In addition, according to the scoring procedure described in the Table 3 shows the environmental and economic sustainability ratings of each strategy, considering that the social sustainability is always the main target. The "decomposition" of the concept sustainability in its three pillars allows to determine its overall level in a methodic way, even if it represents a simplification.

\section{Discussion}

As explained in the Methodology Section, SRS generally promote a weak sustainability approach and accept that economic development can reduce natural capitals. This decreases their capability to measure sustainability in the long term [45]. In fact, SRS are characterized by a difficult integration among different criteria that are only compared with benchmark values (e.g., sustainable sites, water consumption, energy and atmosphere, indoor environmental quality) [70]. Considering the unscientific selection of the criteria, their weights and the benchmarks, this critique is difficult to overcome. Moreover, the aggregated level of assessment, which synthesizes the evaluation in one single rate, reduces the ability to deliver a robust and transparent output [71]. In fact, the use of aggregated rates as outcome of the assessment allows different choices, without being able to map them [45].

Even with its limitations, this study reviews the strategies of the SRS that are globally recognized tools to assess building sustainability due to their solidity and applicability that has fostered their diffusion; to show an extent, in September 2021, almost 140 thousand buildings are registered under LEED all around the world [72].

In the literature, several studies already explore the evolution of Sustainability Rating Systems and their multi-criterion nature based on indicators and benchmarks [49]. However, this is the first research that critically investigates the evidence-based best practices developed to mitigate the spread of infectious diseases and their level of sustainability.

In 2020, WELL, Fitwel and LEED released different evidence-based strategies in response to COVID-19 and other infectious diseases, whose comparison is shown in Table 3.

Regarding the scope of application, WELL is divided in five groups, Fitwel in three and LEED in two. Even if the structure is different, they address similar measures, that are almost identical in the case of the two HBRSs, WELL and Fitwel. Figure 3 shows the relationships within the categories of the three SRS analyzed. Fitwel's strategies addressed in the "Enhance Indoor Environment" category are similar to the ones addressed by WELL's 
"Air and Water Quality Management" and "Cleaning and Sanitization", and they directly impact the "Building Operation" as shown in LEED. On the other hand, LEED's "Cities and Community" category mainly refers to Fitwel's "Encourage Behavioral Change" and "Build Occupant Trust". These aspects are reflected in most of WELL's categories, but especially in "Cleaning and Sanitization Procedures", "Emergency Preparedness Programs", "Health Service Resources" and "Stakeholder Engagement and Communication".

WELL

Fitwel

WELL

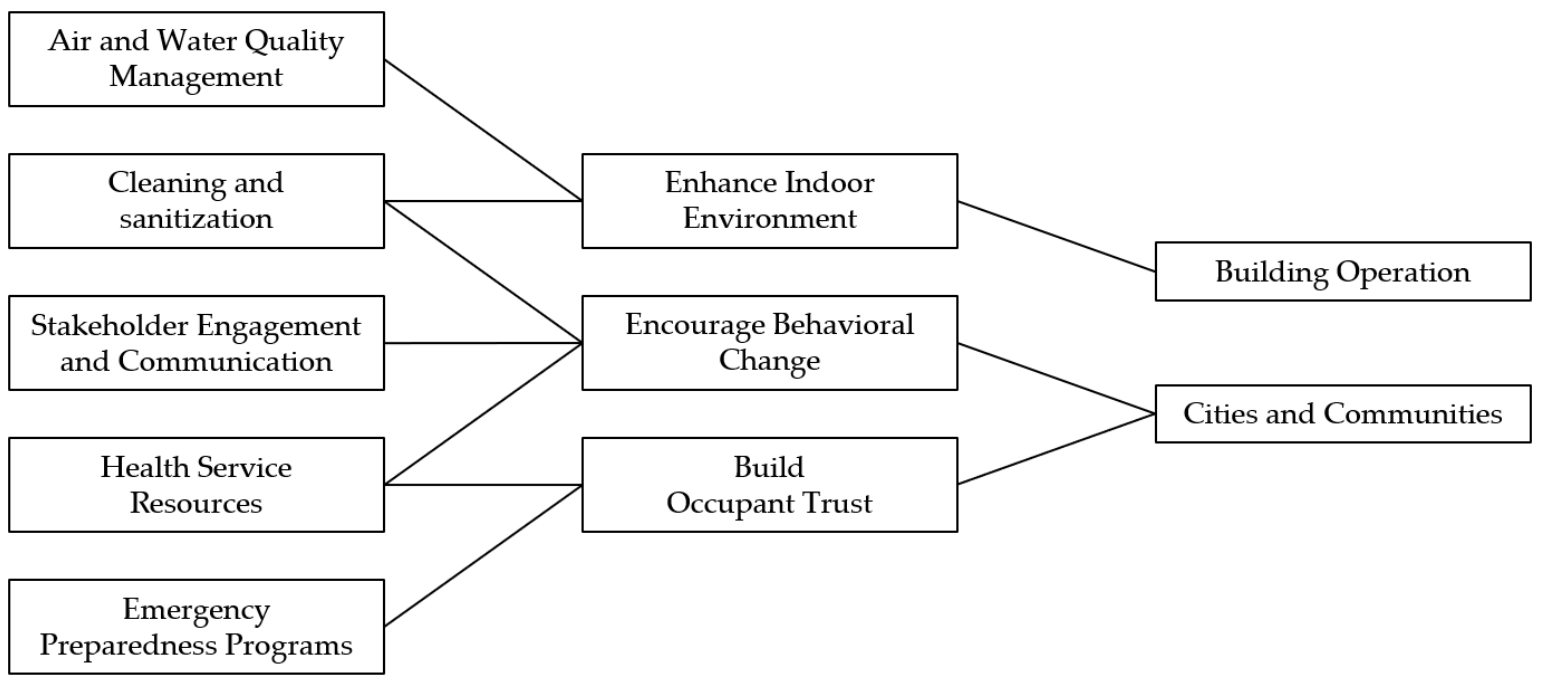

Figure 3. Relationship between the SRS' groups of strategies.

The main concepts considered in WELL and not in Fitwel are food and vaccines. On the other hand, Personal Protective Equipment is strongly addressed in Fitwel while not in WELL. Among the GBRS, only 6 strategies are addressed in LEED, whose extent is obviously limited.

Table 3 also splits the strategies in two main categories: the ones directly related to the built environment (e.g., increased ventilation rates), and the ones that address company policies and are mirrored in the operation and maintenance of indoor spaces (e.g., promote smoke-free environments).

In addition, Table 3 shows the degree of environmental and economic sustainability of each strategy, that already has the highest level of social sustainability, since it is conceived to enhance the human health and safety. Even though the decomposition in the three bottom lines represents a simplification of the concept sustainability, it allows to determine the overall level of sustainability of each strategy in a more methodic and accurate way.

Strategies related to the built environment have a higher environmental and economic impact, thus their environmental and economic sustainability is lower. On the contrary, company policies are easier to implement because they are typically preventive measures (i.e., developed before the emergency), while measures applied to the built environment are typically corrective (i.e., applied during the emergency).

Preventive measures are likely to be adopted at early stages because their implementation is feasible, as explained in Tables 2 and 3 . Due to their sustainable nature, they are also expected to become part of the state-of-the-art in the future, like the strategies described in Table 1, which shows the measures commonly present in modern buildings and introduced with the spread of previous historical infectious diseases.

During emergency situations such as pandemics, strategies referred to the built environment may be adopted in order to guarantee the normal building operation and business continuity. However, these strategies should be put in place only in extreme conditions because they cannot be structural due to their lower level of sustainability. For instance, higher ventilation rates require a higher energy need. If the energy generation is on-site, 
this may also cause higher emissions that can ultimately lead to weaker people due to long-term exposure to poor air quality, as underlined by several studies [73-79].

Human conditions and behavior are strongly related to infectious transmission and symptomatology. As mentioned, people with concomitant pathologies or with an irregular circadian rhythm have a weaker immune system and therefore are more exposed [15-18]. Personal Protective Equipment, social distancing and lockdown of the population are among the most direct and precautionary measures to be taken according to WHO.

SRS aim to ensure that building occupants are safe in their spaces, but also that mutual trust is formed between building occupants and managers, in which everyone does their part to protect and maintain their own health, as well as the well-being of those around them.

However, the strategies developed lack in addressing social distancing in a detailed way. For instance, there are not specific credits that analytically address maximum occupancy rates to minimize airborne cross-infection. This is surprising, considering that the latest experiments highlight that the airborne transmission route is largely the most common $[28,29]$. In particular, WELL and LEED appear to lack strategies that numerically mark provision of restricted access to common areas in addition to maximum occupancy rates in indoor spaces to maintain the recommended physical distancing of 2 meters [80].

\section{Conclusions}

Since the COVID-19 outbreak, buildings have been viewed as a facilitator of disease spread, where the three main transmission routes (contact, droplets, aerosols) are more likely to happen. However, with proper policies and measures in place, buildings can be better prepared for re-occupancy and beyond. If spaces are resilient, their level of sustainability increases and their features are expected to become part of the state-of-the-art in the future, such as the strategies adopted in modern buildings that were originally introduced in response to infectious diseases of the past.

This study reviewed the strategies specifically released by the Sustainability Rating Systems (SRS) WELL, Fitwel and LEED to create indoor environments that can respond to COVID-19 or other respiratory infections. These best practices are internationally applicable, voluntary and focused on the operation of mechanical ventilated office buildings. However, assets that do not fall under these categories (e.g., buildings under construction, retail assets, etc.) may also follow the recommended strategies from early stages to enhance an integrated design process.

The review highlighted that:

- Company policies show a higher environmental and economic sustainability compared to the strategies directly related to the built environment because they are preventive rather than corrective measures.

- The measures addressed by WELL, Fitwel and LEED are similar even though the structure of the SRS is different.

However, the study also underlined several limitations:

- The SRS promote a weak sustainability approach that accepts that economic development can reduce natural capitals.

- The Criteria of the SRS are only compared with benchmark values whose aggregated level of assessment does not allow to map different choices.

- There is a general lack of analytical strategies that address occupancy rates and physical distancing, whose importance is shown in the latest research where the airborne transmission stands out as the main route of infection.

- Fitwel lacks in considering the implications of food and vaccines.

- WELL does not consistently address Personal Protective Equipment.

- LEED is the less solid with only 6 strategies.

Supplementary Materials: The following are available online at https:/ /www.mdpi.com/article/10 $.3390 /$ su132011164/su132011164/s1, Strategies Addressed by the SRS. 
Author Contributions: Conceptualization, A.M., C.P.-A. and A.R.S.; data curation, A.M. and C.P.-A.; formal analysis, A.M. and A.R.S.; investigation, A.M., C.P.-A. and A.R.S.; methodology, A.M., C.P.-A. and A.R.S.; project administration, A.M.; supervision, C.P.-A. and A.R.S.; writing - original draft, A.M., C.P.-A. and A.R.S.; review and editing, A.M. All authors have read and agreed to the published version of the manuscript.

Funding: This research received no external funding.

Institutional Review Board Statement: Not applicable.

Informed Consent Statement: Not applicable.

Data Availability Statement: The study did not report any additional data.

Acknowledgments: The authors would like to express their gratitude to the reviewers of this journal who have offered important and very beneficial insights into this inquiry and have contributed to increase the overall quality of the manuscript.

Conflicts of Interest: The authors declare no conflict of interest.

\section{References}

1. Wagner, E.K. Basic Virology; Blackwell Science: Malden, MA, USA, 1999; ISBN 978-0-632-06109-9.

2. Yin, Y.; Wunderink, R.G. MERS, SARS and Other Coronaviruses as Causes of Pneumonia. Respirology 2017, 23, 130-137. [CrossRef]

3. Hui, D.S.; Azhar, E.I.; Madani, T.A.; Ntoumi, F.; Kock, R.; Dar, O.; Ippolito, G.; Mchugh, T.D.; Memish, Z.A.; Drosten, C.; et al. The Continuing 2019-NCoV Epidemic Threat of Novel Coronaviruses to Global Health-The Latest 2019 Novel Coronavirus Outbreak in Wuhan, China. Int. J. Infect. Dis. 2020, 91, 264-266. [CrossRef]

4. Li, Q.; Guan, X.; Wu, P.; Wang, X.; Zhou, L.; Tong, Y.; Ren, R.; Leung, K.S.M.; Lau, E.H.Y.; Wong, J.Y.; et al. Early Transmission Dynamics in Wuhan, China, of Novel Coronavirus-Infected Pneumonia. N. Engl. J. Med. 2020, 382, 1199-1207. [CrossRef]

5. Zhu, N.; Zhang, D.; Wang, W.; Li, X.; Yang, B.; Song, J.; Zhao, X.; Huang, B.; Shi, W.; Lu, R.; et al. A Novel Coronavirus from Patients with Pneumonia in China, 2019. N. Engl. J. Med. 2020, 382, 727-733. [CrossRef] [PubMed]

6. Nie, J.; Li, Q.; Wu, J.; Zhao, C.; Hao, H.; Liu, H.; Zhang, L.; Nie, L.; Qin, H.; Wang, M.; et al. Establishment and Validation of a Pseudovirus Neutralization Assay for SARS-CoV-2. Emerg. Microbes Infect. 2020, 9, 680-686. [CrossRef] [PubMed]

7. Guo, Y.-R.; Cao, Q.-D.; Hong, Z.-S.; Tan, Y.-Y.; Chen, S.-D.; Jin, H.-J.; Tan, K.-S.; Wang, D.-Y.; Yan, Y. The Origin, Transmission and Clinical Therapies on Coronavirus Disease 2019 (COVID-19) Outbreak-An Update on the Status. Mil. Med Res. $2020,7,11$. [CrossRef] [PubMed]

8. Wilder-Smith, A.; Chiew, C.J.; Lee, V.J. Can We Contain the COVID-19 Outbreak with the Same Measures as for SARS? Lancet Infect. Dis. 2020, 20, e102-e107. [CrossRef]

9. Hu, X.; Ni, W.; Wang, Z.; Ma, G.; Pan, B.; Dong, L.; Gao, R.; Jiang, F. The Distribution of SARS-CoV-2 Contamination on the Environmental Surfaces during Incubation Period of COVID-19 Patients. Ecotoxicol. Environ. Saf. 2021, 208, 111438. [CrossRef] [PubMed]

10. Kumar, P.; Morawska, L. Could Fighting Airborne Transmission Be the next Line of Defence against COVID-19 Spread? City Environ. Interact. 2019, 4, 100033. [CrossRef] [PubMed]

11. Adam, D. A Guide to R-The Pandemic's Misunderstood Metric. Nature 2020, 583, 346-348. [CrossRef]

12. Petersen, E.; Koopmans, M.; Go, U.; Hamer, D.H.; Petrosillo, N.; Castelli, F.; Storgaard, M.; Al Khalili, S.; Simonsen, L. Comparing SARS-CoV-2 with SARS-CoV and Influenza Pandemics. Lancet Infect. Dis. 2020, 20, e238-e244. [CrossRef]

13. Harding, A.; Lanese, N. The 12 Deadliest Viruses on Earth. Available online: https://www.livescience.com/56598-deadliestviruses-on-earth.html (accessed on 12 December 2020).

14. Zhang, M.Q.; Wang, X.H.; Chen, Y.L.; Zhao, K.L.; Cai, Y.Q.; An, C.L.; Lin, M.G.; Mu, X.D. Clinical features of 2019 novel coronavirus pneumonia in the early stage from a fever clinic in Beijing. Zhonghua Jie He He Hu Xi Za Zhi 2020, 43, E013. [CrossRef] [PubMed]

15. Huang, C.; Wang, Y.; Li, X.; Ren, L.; Zhao, J.; Hu, Y.; Zhang, L.; Fan, G.; Xu, J.; Gu, X.; et al. Clinical Features of Patients Infected with 2019 Novel Coronavirus in Wuhan, China. Lancet 2020, 395, 497-506. [CrossRef]

16. Cannizzaro, E.; Ramaci, T.; Cirrincione, L.; Plescia, F. Work-Related Stress, Physio-Pathological Mechanisms, and the Influence of Environmental Genetic Factors. Int. J. Environ. Res. Public Health 2019, 16, 4031. [CrossRef] [PubMed]

17. Cannizzaro, E.; Plescia, F.; Cirrincione, L.; Lo Pinto, E.; Plescia, F. Sport for Job. Differences in Cortisol Levels in a Water Polo Team at Different Times of Workout. EuroMediterr. Biomed. J. 2018, 13, 181-184. [CrossRef]

18. Cannizzaro, E.; Cirrincione, L.; Mazzucco, W.; Scorciapino, A.; Catalano, C.; Ramaci, T.; Ledda, C.; Plescia, F. Night-Time Shift Work and Related Stress Responses: A Study on Security Guards. Int. J. Environ. Res. Public Health 2020, 17, 562. [CrossRef] [PubMed]

19. Singhal, T. A Review of Coronavirus Disease-2019 (COVID-19). Indian J. Pediatr. 2020, 87, 281-286. [CrossRef]

20. World Health Organization. Novel Coronavirus (2019-NCoV): Situation Report; WHO: Geneva, Switzerland, 2020. 
21. Rastogi, P.; Sobek, O.N.; Jephson, G.; Allison, J. A Data-Driven Indoor Air Quality Framework for Post-COVID-19 Workplace Re-Entry: Summary for Policymakers; arbnco Ltd.: Glasgow, UK, 2020.

22. The Society of Heating, Air-Conditioning and Sanitary Engineers of Japan (SHASE); Architectural Institute of Japan (AIJ). Role of Ventilation in the Control of the COVID-19 Infection: Emergency Presidential Discourse; AIJ: Tokyo, Japan, 2020.

23. Peng, X.; Xu, X.; Li, Y.; Cheng, L.; Zhou, X.; Ren, B. Transmission Routes of 2019-NCoV and Controls in Dental Practice. Int. J. Oral Sci. 2020, 12, 1-6. [CrossRef]

24. Bennett, D.H.; McKone, T.E.; Evans, J.S.; Nazaroff, W.W.; Margni, M.D.; Jolliet, O.; Smith, K.R. Defining Intake Fraction. Environ. Sci. Technol. 2002, 36, 207A-211A. [CrossRef]

25. Tellier, R.; Li, Y.; Cowling, B.J.; Tang, J.W. Recognition of Aerosol Transmission of Infectious Agents: A Commentary. BMC Infect. Dis. 2019, 19, 101. [CrossRef]

26. Baron, P. Generation and Behavior of Airborne Particles (Aerosols); Centers for Disease Control and Prevention (CDC): Atlanta, GA, USA, 2020.

27. Sun, C.; Zhai, Z. The Efficacy of Social Distance and Ventilation Effectiveness in Preventing COVID-19 Transmission. Sustain. Cities Soc. 2020, 62, 102390. [CrossRef] [PubMed]

28. Coleman, K.K.; Nguyen, T.T.; Yadana, S.; Hansen-Estruch, C.; Lindsley, W.G.; Gray, G.C. Bioaerosol Sampling for Respiratory Viruses in Singapore's Mass Rapid Transit Network. Sci. Rep. 2018, 8, 17476. [CrossRef] [PubMed]

29. Nishiura, H.; Oshitani, H.; Kobayashi, T.; Saito, T.; Sunagawa, T.; Matsui, T.; Wakita, T.; MHLW COVID-19 Response Team; Suzuki, M. Closed Environments Facilitate Secondary Transmission of Coronavirus Disease 2019 (COVID-19). medRxiv 2020. [CrossRef]

30. Pinheiro, M.D.; Luís, N.C. COVID-19 Could Leverage a Sustainable Built Environment. Sustainability 2020, 12, 5863. [CrossRef]

31. BRE Global Limited. Encouraging Resilient Assets Using BREEAM. BREEAM Resources. Watford, UK, 2020, 10. Available online: https:/ / files.bregroup.com/breeam/BREEAM_Resilience_BRE_115440.pdf (accessed on 4 October 2021).

32. Cazzolla Gatti, R. Coronavirus Outbreak Is a Symptom of Gaia's Sickness. Ecol. Model. 2020, 426, 109075. [CrossRef]

33. M'ikanatha, N.M. The Pandemic Century: One Hundred Years of Panic, Hysteria and Hubris. Emerg. Infect. Dis. J. 2020, 26, 450. [CrossRef]

34. Bruun, C. The Water Supply of Ancient Rome. A Study of Roman Imperial Administration. Soc. Sci. Fenn. 1991, 10, 456.

35. Lilley, K.D. Urban Planning after the Black Death: Townscape Transformation in Later Medieval England (1350-1530). Urban Hist. 2015, 42, 22-42. [CrossRef]

36. Jordan, D.P. Transforming Paris: The Life and Labors of Baron Haussmann; University of Chicago Press: Chicago, IL, USA, 1996; ISBN 978-0-226-41038-8.

37. Kirkland, S. Paris Reborn: Napoléon III, Baron Haussmann, and the Quest to Build a Modern City; St. Martin's Press: New York, NY, USA, 2013; ISBN 978-0-312-62689-1.

38. Adams, A.; Schwartzman, K.; Theodore, D. Collapse and Expand: Architecture and Tuberculosis Therapy in Montreal, 1909, 1933, 1954. Technol. Cult. 2010, 49, 908-942. [CrossRef]

39. Campbell, M. What Tuberculosis Did for Modernism: The Influence of a Curative Environment on Modernist Design and Architecture. Med. Hist. 2005, 49, 463-488. [CrossRef] [PubMed]

40. Megahed, N.A.; Ghoneim, E.M. Antivirus-Built Environment: Lessons Learned from Covid-19 Pandemic. Sustain. Cities Soc. 2020, 61, 102350. [CrossRef]

41. Reyes, R.; Ahn, R.; Thurber, K.; Burke, T.F. Urbanization and Infectious Diseases: General Principles, Historical Perspectives, and Contemporary Challenges. In Challenges in Infectious Diseases; Fong, I.W., Ed.; Emerging Infectious Diseases of the 21st Century; Springer: New York, NY, USA, 2013; pp. 123-146, ISBN 978-1-4614-4496-1.

42. Ott, M.; Shaw, S.F.; Danila, R.N.; Lynfield, R. Lessons Learned from the 1918-1919 Influenza Pandemic in Minneapolis and St. Paul, Minnesota. Public Health Rep. 2007, 122, 803-810. [CrossRef]

43. Baldwin, A.N. Sars and the Built Environment in Hong Kong. In Proceedings of the Institution of Civil Engineers-Municipal Engineer; Thomas Telford Ltd.: London, UK, 2006; Volume 159, pp. 37-42. [CrossRef]

44. Centers for Disease Control and Prevention, (CDC). Hierarchy of Controls I NIOSH I CDC. Available online: https://www.cdc. gov/niosh/topics/hierarchy/default.html (accessed on 12 December 2020).

45. Berardi, U. Sustainability Assessment of Urban Communities through Rating Systems. Environ. Dev. Sustain. 2013, 15, $1573-1591$. [CrossRef]

46. Wen, B.; Musa, N.; Onn, C.C.; Ramesh, S.; Liang, L.; Wang, W. Evolution of Sustainability in Global Green Building Rating Tools. J. Clean. Prod. 2020, 259, 120912. [CrossRef]

47. McArthur, J.J.; Powell, C. Health and Wellness in Commercial Buildings: Systematic Review of Sustainable Building Rating Systems and Alignment with Contemporary Research. Build. Environ. 2020, 171, 106635. [CrossRef]

48. International WELL Building Institute. Strategies from the WELL Building Standard to Support in the Fight against COVID-19; IWBI: New York, NY, USA, 2020.

49. Devuyst, D. Linking Impact Assessment and Sustainable Development at the Local Level: The Introduction of Sustainability Assessment Systems. Sustain. Dev. 2000, 8, 67-78. [CrossRef]

50. Building Research Establishment. Building Back Better with BREEAM: Supporting the Green Recovery; BRE Global Limited: Watford, UK, 2020. 
51. RESET Standard. RESET Indexes for Airborne Viral Transmission. Available online: https://www.reset.build/resources/indexes (accessed on 31 January 2021).

52. International WELL Building Institute. WELL Building Standard. Available online: https://www.wellcertified.com/ (accessed on 2 January 2021).

53. U.S. Green Building Council USGBC. Releases New LEED Guidance to Address COVID-19 and Support Buildings with Reopening Strategies. Available online: https://www.usgbc.org/articles/usgbc-releases-new-leed-guidance-address-covid-19 -and-support-buildings-reopening (accessed on 28 August 2021).

54. Center for Active Design Fitwel. Available online: https:/ /www.fitwel.org/ (accessed on 6 January 2021).

55. Qian, H.; Miao, T.; Liu, L.; Zheng, X.; Luo, D.; Li, Y. Indoor Transmission of SARS-CoV-2. Indoor Air 2020, 1-7. [CrossRef] [PubMed]

56. Alexander, A.; De Smet, A.; Langstaff, M.; Ravid, D. What Employees Are Saying about the Future of Remote Work; McKinsey \& Company: Houston, TX, USA, 2021.

57. D'Alessandro, D.; Gola, M.; Appolloni, L.; Dettori, M.; Fara, G.M.; Rebecchi, A.; Settimo, G.; Capolongo, S. COVID-19 and Living Space Challenge. Well-Being and Public Health Recommendations for a Healthy, Safe, and Sustainable Housing. Acta Bio Med. 2020, 91, 61-75. [CrossRef]

58. Tokazhanov, G.; Tleuken, A.; Guney, M.; Turkyilmaz, A.; Karaca, F. How Is COVID-19 Experience Transforming Sustainability Requirements of Residential Buildings? A Review. Sustainability 2020, 12, 8732. [CrossRef]

59. Spennemann, D. Residential Architecture in a Post-Pandemic World: Implications of COVID-19 for New Construction and for Adapting Heritage Buildings. J. Green Build. 2021, 16, 199-215. [CrossRef]

60. Kaklauskas, A.; Lepkova, N.; Raslanas, S.; Vetloviene, I.; Milevicius, V.; Sepliakov, J. COVID-19 and Green Housing: A Review of Relevant Literature. Energies 2021, 14, 2072. [CrossRef]

61. World Commission on Environment and Development. Our Common Future; Oxford University Press: Oxford, UK; New York, NY, USA, 1987; ISBN 978-0-19-282080-8.

62. Nilsen, H.R. The Joint Discourse 'Reflexive Sustainable Development' -From Weak towards Strong Sustainable Development. Ecol. Econ. 2010, 69, 495-501. [CrossRef]

63. Pelenc, J.; Ballet, J. Strong Sustainability, Critical Natural Capital and the Capability Approach. Ecol. Econ. 2015, 112, 36-44. [CrossRef]

64. Zugravu-Soilita, N.; Kafrouni, R.; Bouard, S.; Apithy, L. Do Cultural Capital and Social Capital Matter for Economic Performance? An Empirical Investigation of Tribal Agriculture in New Caledonia. Ecol. Econ. 2021, 182, 106933. [CrossRef]

65. International WELL Building Institute. WELL Health-Safety Rating for Facility Operations and Maintenance; IWBI: New York, NY, USA, 2020.

66. Center for Active Design. Fitwel Viral Response Module: Reference Guide; Center for Active Design: New York, NY, USA, 2020.

67. U.S. Green Building Council. LEED Reference Guide for Building Operations and Maintenance, v4 ed.; U.S. Green Building Council: Washington, DC, USA, 2013; ISBN 978-1-932444-20-9.

68. U.S. Green Building Council. COVID-19 Resources. Available online: https://www.usgbc.org/about/covid-19-resources (accessed on 10 January 2021).

69. GIGA: Performance-Driven ESG Data for Real-Estate. Certification for Health \& Regeneration Focused on Indoor Air Quality. RESET Standard. Québec, Canada 2017. Available online: https:/ / reset.build/download/RESET_Standard_v2_0_prerelease_17 0312.pdf (accessed on 4 October 2021).

70. Bourdic, L.; Salat, S. Building Energy Models and Assessment Systems at the District and City Scales: A Review. Build. Res. Inf. 2012, 40, 518-526. [CrossRef]

71. Mori, K.; Christodoulou, A. Review of Sustainability Indices and Indicators: Towards a New City Sustainability Index (CSI). Environ. Impact Assess. Rev. 2012, 32, 94-106. [CrossRef]

72. U.S. Green Building Council. LEED Project Profiles. Available online: https://www.usgbc.org/projects (accessed on 29 August 2021).

73. Filippini, T.; Rothman, K.J.; Cocchio, S.; Narne, E.; Mantoan, D.; Saia, M.; Goffi, A.; Ferrari, F.; Maffeis, G.; Orsini, N.; et al. Associations between Mortality from COVID-19 in Two Italian Regions and Outdoor Air Pollution as Assessed through Tropospheric Nitrogen Dioxide. Sci. Total Environ. 2020, 760, 143355. [CrossRef]

74. Huang, G.; Brown, P.E. Population-Weighted Exposure to Air Pollution and COVID-19 Incidence in Germany. Spat. Stat. 2021, 41, 100480. [CrossRef] [PubMed]

75. Liang, D.; Shi, L.; Zhao, J.; Liu, P.; Sarnat, J.A.; Gao, S.; Schwartz, J.; Liu, Y.; Ebelt, S.T.; Scovronick, N.; et al. Urban Air Pollution May Enhance COVID-19 Case-Fatality and Mortality Rates in the United States. Innovation 2020, 1, 100047. [CrossRef]

76. Razzaq, A.; Sharif, A.; Aziz, N.; Irfan, M.; Jermsittiparsert, K. Asymmetric Link between Environmental Pollution and COVID-19 in the Top Ten Affected States of US: A Novel Estimations from Quantile-on-Quantile Approach. Environ. Res. 2020, 191, 110189. [CrossRef]

77. Travaglio, M.; Yu, Y.; Popovic, R.; Selley, L.; Leal, N.S.; Martins, L.M. Links between Air Pollution and COVID-19 in England. Environ. Pollut. 2021, 268, 115859. [CrossRef] [PubMed]

78. Konstantinoudis, G.; Padellini, T.; Bennett, J.; Davies, B.; Ezzati, M.; Blangiardo, M. Long-Term Exposure to Air-Pollution and COVID-19 Mortality in England: A Hierarchical Spatial Analysis. Environ. Int. 2021, 146, 106316. [CrossRef] [PubMed] 
79. López-Feldman, A.; Heres, D.; Marquez-Padilla, F. Air Pollution Exposure and COVID-19: A Look at Mortality in Mexico City Using Individual-Level Data. Sci. Total Environ. 2021, 756, 143929. [CrossRef] [PubMed]

80. Stewart, E.J.; Schoen, L.J.; Mead, K.; Olmsted, R.N.; Sekhar, C.; Vernon, W.; Pantelic, J.; Li, Y.; Sultan, Z.M.; Conlan, W. ASHRAE Position Document on Infectious Aerosols; ASHRAE: Atlanta, GA, USA, 2020. 